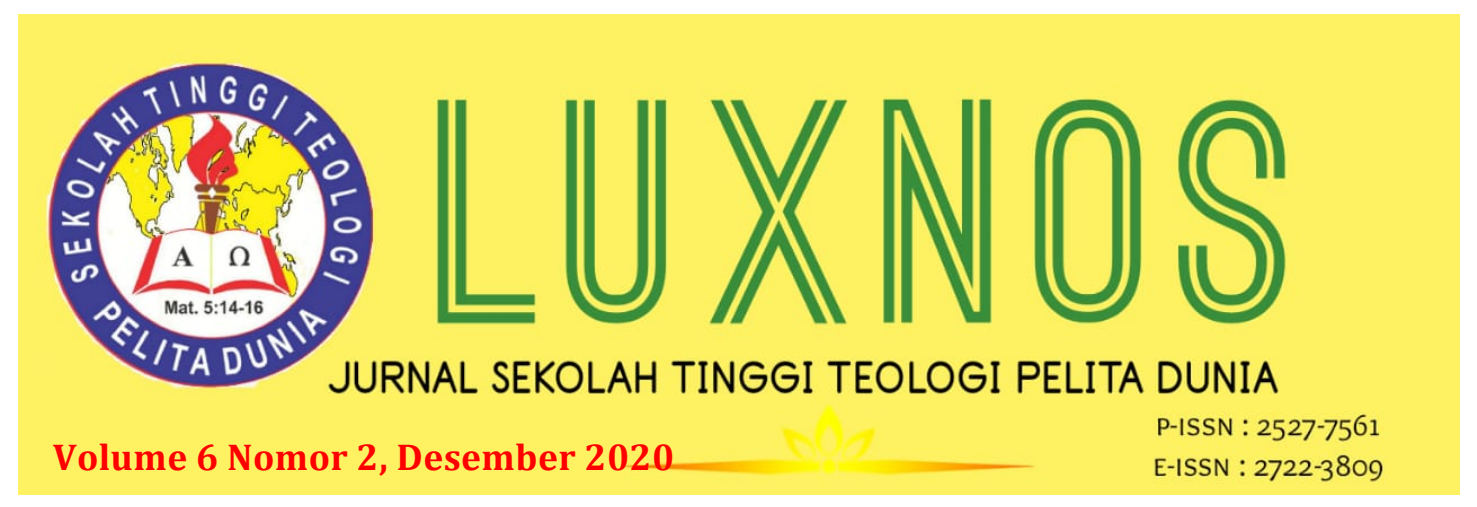

\title{
Peningkatan Kinerja Guru Pendidikan Agama Kristen Di Era Disrupsi Dan Pandemi
}

\author{
Abraham Tefbana ${ }^{1}$ \\ ${ }^{1}$ Sekolah Tinggi Teologi Pelita Dunia ${ }^{1}$ \\ tefbana.abraham@gmail.com
}

\section{A. Danny Kia ${ }^{2}$ \\ 2Universitas Kristen Indonesia \\ armandhodannyk@gmail.com}

\begin{abstract}
The era of disruption is not only a distraction to stability, stability, and comfort, but must be interpreted, viewed and utilized as an opportunity to innovate in improving competence and performance to evolve in the revolution. Meanwhile, covid-19 pandemic is an epidemic that spreads in various countries including Indonesia, so it not only disrupts but paralyzes all human movement joints in all areas including the implementation of education. From this explanation it is understandable that the era of disruption and pandemic covid-19 are two different events, but equally disturbing, limiting and even paralyzing human wiggle room in all the joints of life. This era of disruption and pandemic becomes a challenge but also an opportunity, because on the one hand it is disturbing, while on the other hand forcing people to think creatively and innovatively to be able to develop self-competence and even improve performance in order to make the era of disruption and pandemic as an opportunity to achieve success. The improvement and development of Christian Education teachers in the era of disruption and pandemic is very decisive in the successful implementation of Christian Education. This paper examines efforts to improve christian education teacher performance in the era of disruption and pandemic, through seminars, training, courses and even further studies as an effort to improve human resources.
\end{abstract}




\section{JURNAL LUXNOS \\ Volume 6 Nomor 2, Desember 2020}

Keywords: In an era of disruption and pandemics, teachers of religious education, improved performance.

Abstrak: Era disrupsi tidak hanya sebagai gangguan terhadap kestabilan, kemapanan, dan kenyamanan, tapi harus dimaknai, dipandang dan dimanfaatkan sebagai sebuah peluang untuk berinovasi dalam meningkatkan kompetensi dan kinerja untuk berevolusi dalam revolusi. Sedangkan pandemic covid -19 merupakan wabah yang menyebar diberbagai negara termasuk Indonesia, sehingga tidak hanya mengganggu tetapi melumpuhkan semua sendi pergerakan manusia di segala bidang termasuk pelaksanaan pendidikan. Dari penjelasan ini dapat dipahami bahwa era disrupsi dan pandemic covid -19 merupakan dua peristiwa yang berbeda, namun sama-sama mengganggu, membatasi dan bahkan melumpuhkan ruang gerak manusia dalam segala sendi kehidupan. Era disrupsi dan pandemic ini menjadi tantangan tapi juga peluang, sebab pada satu sisi mengganggu, sedangkan pada sisi yang lain lagi memaksa manusia untuk berpikir kreatif dan inovatif untuk dapat mengembangkan kompetensi diri bahkan meningkatkan kinerja agar menjadikan era disrupsi dan pandemic sebagai kesempatan dalam meraih keberhasilan. Peningkatan dan pengembangan kinerja guru Pendidikan Agama Kristen di era disrupsi dan pandemic sangat menentukan keberhasilan pelaksanaan Pendidikan Kristen. Tulisan ini mengkaji upaya peningkatan kinerja guru PAK di era disrupsi dan pandemic, melalui seminar, pelatihan, kursus dan bahkan studi lanjut sebagai upaya peningkatan sumber daya manusia.

Kata Kunci: Di era disrupsi dan pandemic, guru pendidikan agama kristen, peningkatan kinerja.

\section{Pendahuluan}

Istilah disrupsi dari kata "disruption" yang mula-mula muncul dalam konteks bisnis, investasi dan keuangan. ${ }^{1}$ Istilah "disruption" ini kemudian berkembang dan meluas penggunaannya oleh berbagai bidang kehidupan manusia, baik itu oleh birokrasi pemerintahan, pelayanan sosial, dunia politik, kepemimpinan dan juga pendidikan. Istilah disrupsi menjadi sangat populer dikalangan pendidikan tinggi karena artikel Prof. Sudaryono tentang "Bunuh Diri Masal Perguruan Tinggi Menuju Pendidikan Asembling", yang menjadi viral di media sosial selama kurang lebih dua tahun. Namun, dunia pendidikan tinggi di

\footnotetext{
${ }^{1}$ Rhenald Kasali, Disruption: Tak ada yang tak bisa diubah sebelum dihadapi, Motivasi saja tidak cukup (Jakarta: Gramedia Pustaka Utama, 2017), hlm.139.
} 


\section{JURNAL LUXNOS}

Volume 6 Nomor 2, Desember 2020

Indonesia tidak boleh memahami artikel Prof. Sudaryono hanya dari sisi negatifnya saja, tapi juga harus dipahami sisi positifnya.

Disrupsi tidak hanya dipahami sebagai gangguan terhadap kinerja guru Pendidikan Agama Kristen (PAK), tetapi juga harus diresponi sebagai peluang bagi guru PAK untuk mengembangkan kompetensi diri bagi kualitas kinerjanya dalam dunia pendidikan untuk tetap bertahan dan berkualitas di era disrupsi. Karena kinerja (hasil kerja) guru PAK sebagai bukti kualitas kerjanya yang dilihat dan dinikmati orang lain. Kinerja merupakan hasil kerja baik secara kuantitas maupun kualitas selama kurun waktu tertentu, yang terukur dan bermanfaat bagi orang lain.

\section{Metode Penelitian}

Penelitian ini menggunakan metode penelitian kualitatif deskriptif analisis. Metode ini untuk menggambarkan isi dari informasi yang diperoleh. Penelitian kualitatif deskripstif merupakan argumentasi-argumentasi logis yang berkualitas dan sistematis dalam mengadakan pengamatan, pengumpulan dan pengolahan informasi sampai menghasilkan artikel ilmiah. Metode kualitatif deskriptif ini dipilih untuk menjelaskan data dan fakta yang diperoleh, melalui argumentasiargumentasi logis agar memudahkan dalam mempelajari dan mengaplikasikannya dalam peningkatan kinerja guru Pendidikan Agama Kristen (PAK) di era disrupsi dan pandemic covid-19. Sumber materi dari artikel ini dari jurnal-jurnal ilmiah dan sumber-sumber ilmiah lainnya.

\section{Hasil dan Pembahasan}

1. Era disrupsi dan pandemi

a. Era disrupsi ${ }^{2}$

Apa pengertiannya disrupsi? dan Apa dampak perkembangan era disrupsi terhadap pendidikan di Indonesia? Apakah benar era disrupsi mengancam perkembangan pendidikan di Indonesia? Dalam menanggapi ancaman era disrupsi terhadap perkembangan Perguruan Tinggi maka Prof. Sudaryono mengatakan, bahwa "Bunuh Diri Masal Perguruan Tinggi Menuju Pendidikan

\footnotetext{
${ }^{2}$ Secara bahasa, disruption artinya gangguan atau kekacauan; gangguan atau masalah yang mengganggu suatu peristiwa, aktivitas, atau proses (disturbance or problems which interrupt an event, activity, or process).Dalam Kamus Besar Bahasa Indonesia, pengertian disrupsi adalah hal tercabut dari akarnya. https://romeltea.com/pengertian-disrupsi-dan-contohnya/. Diakses, 1 Oktober 2020.
} 


\section{JURNAL LUXNOS}

Volume 6 Nomor 2, Desember 2020

Asembling". ${ }^{3}$ Topik jurnal ini menjadi diskusi dan perdebatan hangat yang viral di media sosial perihal universities disruption yang dipicu artikel Jim Clifton, dengan judul "Universities: Disruption is Coming". Isinya secara garis besar mempertanyakan dan mengkhawatirkan peran masa depan pendidikan tinggi dalam menyuplai tenaga kerja industri di dunia. Terbitnya artikel Jim Clifton ini sebagai respon dan tanggapan atas iklan Google dan Ernst \& Young dengan konten, akan menggaji siapapun yang bisa bekerja dengannya tanpa harus memiliki ijazah apa pun, termasuk ijazah dari perguruan tinggi (PT). ${ }^{4}$ Dalam konteks ini, harus memahami disrupsi bagi perguruan tinggi dan berbagai sendi kehidupan seluruh dunia termasuk di Indonesia sebagai dampak perkembangan ilmu pengetahuan dan teknologi dimana saat ini dunia sedang berada di era revolusi industri 4.0.5 Dengan demikian, maka disrupsi harus dipahami secara komprehensif, baik secara positif maupun negative. Karena era disrupsi terhadap kemapanan, keamanan dan kenyamanan, namun disrupsi dapat dimanfaatkan sebagai peluang untuk meningkatkan kompetensi bagi peningkatan kinerja agar bisa di dunia kerja di era revolusi industri 4.0

Dampak dari perkembangan ilmu pengetahuan dan teknologi yang saat ini membawa dunia berada di era revolusi industri 4.0 adalah era disrupsi. Dengan kata lain disrupsi sebagai dampak dari era revolusi industri 4.0. Dampak terbesar era disrupsi ialah kehidupan pribadi manusia yang secara sadar atau tidak sadar sedang berada didalam arus gelombang revolusi industri 4.0 dan memaksanya untuk meninggalkan kehidupan tradisional dan konvesional untuk hidup di era digitalisasi. Dampak era disrupsi terhadap semua lini kehidupan manusia termasuk pelaksanaan pendidikan.

Era revolusi industri 4.0 mengubah konsep pekerjaan, struktur pekerjaan, dan kompetensi yang dibutuhkan dunia pekerjaan. Sebuah survei perusahaan

\footnotetext{
${ }^{3}$ Sudaryono, “Bunuh Diri Masal Perguruan Tinggi Menuju Pendidikan Asembling, ” Kompas (31 Agustus 2017). http://amikhb.ac.id/detailpost/bunuh-diri-masal-perguruan-tinggi-menujupendidikan-asembling. Diakses 1Oktober 2020.

${ }^{4}$ Sudaryono, Bunuh Diri Masal Perguruan Tinggi Menuju Pendidikan Asembling. AMIK Harapan Bangsa. Sumber: http://amikhb.ac.id/detailpost/bunuh-diri-masal-perguruan-tinggimenuju-pendidikan-asembling.

${ }^{5}$ Industri 4.0 adalah nama tren otomasi dan pertukaran data terkini dalam teknologi pabrik. Istilah ini mencakup sistem siber-fisik, internet untuk segala, komputasi awan, dan komputasi kognitif. https://id.wikipedia.org/wiki/Industri_4.0. Diakses, 1 Oktober 2020.
} 


\section{JURNAL LUXNOS}

Volume 6 Nomor 2, Desember 2020

perekrutan internasional, Robert Walters, bertajuk Salary Survey 2018 menyebutkan, fokus pada transformasi bisnis ke platform digital telah memicu permintaan profesional sumber daya manusia (SDM) yang memiliki kompetensi yang jauh berbeda dari sebelumnya. Era revolusi industri 4.0 juga mengubah cara pandang tentang pendidikan. Perubahan yang dilakukan tidak hanya sekadar cara mengajar, tetapi jauh yang lebih esensial, yakni perubahan cara pandang terhadap konsep pendidikan itu sendiri. ${ }^{6}$ Era revolusi industri 4.0 merupakan tantangan berat bagi guru Indonesia. Dalam pembahasan ini Sukartono mengutip pernyataan Jack Ma dalam pertemuan tahunan World Economic Forum 2018 bahwa pendidikan adalah tantangan besar abad ini. Jika tidak mengubah cara mendidik dan belajar-mengajar, 30 tahun mendatang kita akan mengalami kesulitan besar.

Jika pelaksanaan pendidikan dan pembelajaran di Indonesia mengabaikan muatan keterampilan, maka lulusan tidak akan mampu berkompetisi di era teknologi digital. Hal ini menuntut agar kurikulum pendidikan di Indonesia diubah dan disesuaikan dengan tututan zaman agar meluluskan tenaga-tenaga terampil yang mampu berkompetisi dalam dunia kerja yang berbasis teknologi industri. Guru-guru di Indonesia harus siap mengembangkan kompetensi sebagai upaya peningkatan kinerja di era revolusi industri 4.0, sehingga mampu menciptakan pembelajaran kreatif dan inovatif secara mandiri. Karena era disrupsi memaksa agar sistem pendidikan diperbarui dan disesuaikan dengan tuntutan era revolusi 4.0 diantaranya gerakan literasi baru yang berfokus pada tiga literasi utama yaitu: 1). Literasi digital diarahkan pada tujuan peningkatan kemampuan membaca, menganalisis, dan menggunakan informasi di dunia (Big Data). 2). Literasi teknologi bertujuan untuk memberikan pemahaman pada cara kerja mesin dan aplikasi teknologi, dan 3). Literasi manusia diarahkan pada peningkatan kemampuan berkomunikasi dan penguasaan ilmu desain (Aoun, 2017). ${ }^{7}$ Ketiga literasi ini sangat dibutuhkan sebagai ketrampilan dalam persaingan di dunia kerja di era industri 4.0. Ketidaksiapan guru dalam meningkatkan kompetensi dirinya untuk pengembangan pembelajaran digital

\footnotetext{
${ }^{6}$ Sukartono, Revolusi Industri 4.0 dan Dampaknya terhadap Pendidikan di Indonesia, FIP PGSD Universitas Muhammadiyah Surakarta. fkip.ums.ac.id/.../Revolusi-Industri-4.0-dan-Dampaknyaterhadap- Pendidikan-di-Indonesia-Dr.-Sukartono.doc. Diakses, 2 Oktober 2020

${ }^{7}$ Sukartono, Revolusi Industri 4.0 dan Dampaknya terhadap Pendidikan di Indonesia, FIP PGSD Universitas Muhammadiyah Surakarta. Diakses, 2 Oktober 2020.
} 


\section{JURNAL LUXNOS}

Volume 6 Nomor 2, Desember 2020

dan teknologi secara kreatif dan inovatif, akan menjadi disrupsi dalam dunia pendidikan. Penggunaan dan pengembangan literasi baru untuk melengkapi literasi lama dengan melakukan penyesuaian kurikulum pendidikan dan sistem pembelajaran yang diharapkan dapat menghasilkan lulusan yang kompeten di era revolusi industri 4.0 .

b. Era Pandemic - Covid

Pada 31 Desember 2019 muncul kasus serupa dengan pneumonia yang tidak diketahui di Wuhan, China. ${ }^{8}$ Kemudian dari kasus ini dikenal dengan nama Corona Virus Desease-2019 (Covid-19). Dari data organisasi Kesehatan Dunia yaitu World Health Organization (WHO) dibawah Perserikatan Bangsa-Bangsa diperoleh bahwa Covid-19 telah menjadi pandemic global yang terkonfirmasi telah menyebar di 216 negara di seluruh dunia (Update: 17-05-2020). ${ }^{9}$ Virus Corona juga telah mewabah di Indonesia sejak awal Maret hingga saat ini 2 Oktober 2020, Kasus positif Covid-19 bertambah 4.174 kasus menjadi 291.182 kasus. Angka kesembuhan bertambah 3.540 kasus menjadi 218.487 kasus. Pasien meninggal bertambah 116 kasus menjadi 10.856 kasus. ${ }^{10}$ Dampak penyebaran pandemi Covid-19 telah mengubah berbagai aspek kehidupan manusia. Sejak mewabahnya covid-19 di Indonesia pemerintah telah mengeluarkan berbagai kebijakan untuk mencegah penyebarannya dengan memberlakukan social distancing, physical distancing hingga pemberlakuan Pembatasan Sosial Bersekala Besar (PSBB) di daerah-daerah yang dikategorikan zona merah. Kebijakan-kebijakan yang dikeluarkan pemerintah untuk mencegah penyebaran covid-19 menimbulkan dampak bagi semua bidang kehidupan manusia termasuk pendidikan di Indonesia.

\footnotetext{
${ }^{8}$ Abidah, A., Hidaayatullaah, H. N., Simamora, R. M., Fehabutar, D., \& Mutakinati, L. (2020). The Impact of Covid-19 to Indonesian Education and Its Relation to the Philosophy of " Merdeka Belajar." Studies in Philosophy of Science and Education, 1(1), 38-49. https://sciejournal.com/index.php/SiPoSE/article/view/9. Diakses, 2 Oktober 2020.

9 Luh Devi Herliandry*1, Nurhasanah2, Maria Enjelina Suban 3, Heru Kuswanto4, Pembelajaran Pada Masa Pandemi Covid-19. Jurnal Teknologi Pendidikan http://journal.unj.ac.id/unj/index.php/jtp Vol. 22, No. 1, April 2020, e-ISSN: 2620-3081; p-ISSN: 1411-2744; DOI:https://doi.org/10. 21009/jtp.v22i1.15286. Diakses, 2 Oktober 2020.

${ }^{10}$ Merdeka.com, Data Terkini Jumlah Korban Virus Corona di Indonesia. Tanggal 1 Oktober 2020. https://www.merdeka.com/peristiwa/data-terkini-jumlah-korban-virus-corona-di-indonesia.html. Diakses, 2 Oktober 2020.
} 


\section{JURNAL LUXNOS \\ Volume 6 Nomor 2, Desember 2020}

Pandemic covid-19 menyebabkan disrupsi bagi pendidikan yang mendesak pemerintah mengeluarkan kebijakan untuk memberlakukan pelaksanaan pendidikan jarak jauh yang hampir belum pernah diberlakukan secara menyeluruh di semua jenjang pendidikan di Indonesia. Pelaksanaan pendidikan jarak jauh sebagai disrupsi pendidikan dalam proses belajar mengajar bagi semua elemen pendidikan terkhususnya peserta didik, pendidik, tenaga kependidikan dan orang tua. Hal ini dapat disikapi baik sebagai tantangan ataupun peluang oleh semua elemen di semua jenjang pendidikan dalam melaksanakan proses belajar mengajar agar tetap aktif walaupun secara jarak jauh. Pandemic Covid-19 telah mempelopori pelaksanaan pembelajaran online secara menyeluruh di Indonesia.

Di era disrupsi pendidikan ini, para guru termasuk guru Pendidikan Agama Kristen (PAK) sebagai elemen penting dalam pelaksanaan pendidikan jarak jauh dipaksa untuk mengubah kurikulum, metode, strategi, media serta berbagai infrastruktur terkait pelaksanaan belajar mengajar secara menyeluruh yang belum pernah dilakukan dalam pelaksanaan pembelajaran konvensional ke pelaksanaan pendidikan online dan jarak jauh. Pembelajaran online dan jarak jauh didukung dengan perkembangan teknologi digital era revolusi industri 4.0. Pembelajaran online secara efektif untuk melaksanakan pembelajaran meskipun pendidik dan peserta didik berada di tempat yang berbeda. ${ }^{11}$ Pembelajaran online di era disrupi pandemic covid-19 diterapkan sebagai pengalaman transfer pengetahuan menggunakan video, audio, gambar, komunikasi teks, perangkat lunak dan dengan dukungan jaringan internet. Infrastruktur pendukung pembelajaran online di era disrupsi pandemic covid -19 melalui aplikasi-aplikasi yang tersedia seperti Zoom, Google meet, Google Classroom, Microsoft teams, Whatsapp, Telegram, active presenter dan berbagai fitur aplikasi lainnya.

Google Clasroom juga memungkinkan pendidik dan guru mengembangkan pembelajaran kreatif. Diskusi dan transfer pengetahuan secara face-to-face layaknya bertemu melalui beragam platform video teleconference yang banyak tersedia gratis seperti Zoom dan Google Meet. Platform tersebut menjadikan pendidik dan peserta didik untuk bertemu dan berinteraksi secara virtual

${ }^{11}$ Verawardina, U., Asnur, L., Lubis, A. L., \& Hendriyani, Y. (2020). Reviewing Online Learning Facing the Covid-19 Outbreak. 12(3), 385-392. Diakses, 2 Oktober 2020 


\section{JURNAL LUXNOS \\ Volume 6 Nomor 2, Desember 2020}

dengan fasilitas pesan instan dan kegiatan presentasi. ${ }^{12}$ Interaksi pembelajaran tatap muka untuk presentasi tugas dan diskusi antara guru dan peserta didik dapat dilakukan melalui aplikasi Zoom, Google meet, Google Classroom, Microsoft team dan palikasi lainnya layaknya di ruang kelas hanya saja secara jarak jauk. Sedangkan Fitur Whatsapp mencakup Whatsapp Group yang dapat digunakan untuk mengirim pesan teks, gambar, video dan file dalam berbagai format kepada semua anggota. ${ }^{13}$ Selain melaksanakan pembelajaran tatap muka melalui beragam platform video teleconference juga tersedia aplikasi-aplikasi seperti Whatsapp dan telegram untuk guru mengirim pesan teks, gambar, video dan file dalam berbagai format kepada semua anggota group agar tetap berkomunikasi dan mendiskusikan materi-materi ajar dengan para peserta didik. Bahkan Kementrian Pendidikan dan Kebudayaan berinisiatif untuk menyiarkan berbagai konten edukasi secara nasional untuk jenjang pendidikan dasar dan menengah sesuai dengan kurikulum nasional melalui televisi pada saluran TVRI.

Era disrupsi pandemic covid-19 menjadi peluang bagi guru dalam peningkatan komptensi dan kinerjanya sehingga dapat memanfaatkan berbagai platform aplikasi media online dalam menunjang proses pembelajaran jarak jauh dari rumah. Interaksi pembelajaran online yang dilakukan mulai dari diskusi, presentasi hingga pemberian tugas melatih kemandirian belajar para peserta didik. Karena pembelajaran online memacu para peserta didik untuk meningkatkan perilaku belajar secara mandiri melalui observasi-observasi untuk menyelesaikan tugas-tugas belajar, seperti membaca, memaknai postingan diskusi dan mendiskusikan video atau konten pembelajaran dari gurunya. Perilaku ini akan membiasakan peserta didik untuk berupaya menemukan berbagai informasi pengetahuan sesuai tugas-tugas belajarnya secara mandiri dari rumahnya.

Belajar online menuntut peran pendidik mengevaluasi efektivitas dan disesuaikan dengan kebutuhan belajar. Ini penting dilakukan untuk tetap memenuhi aspek pembelajaran seperti proses pengetahuan, moral,

${ }^{12}$ Wiranda, T., \& Adri, M. (2019). Rancang Bangun Aplikasi Modul Pembelajaran Teknologi WAN Berbasis Android. VoteTEKNIKA (Vocational Teknik Elektronika Dan Informatika), 7(4), 2302-3295. Diakses, 2 Oktober 2020.

${ }^{13}$ Kusuma, J. W., \& Hamidah. (2020). Platform Whatsapp Group Dan Webinar Zoom Dalam Pembelajaran Jarak Jauh Pada Masa Pandemik Covid 19. Jurnal Ilmiah Pendidikan Matematika Volume, 5(1). Diakses, 2 Oktober 2020. 


\section{JURNAL LUXNOS}

Volume 6 Nomor 2, Desember 2020

keterampilan, kecerdasan dan estetika. Mengingat bahwa perubahan ke pembelajaran online secara tidak langsung berpengaruh pada daya serap peserta didik. ${ }^{14}$ Guru dapat memantau dan mengetahui aktivitas belajar para peserta didiknya, dengan membangun komunikasi secara intens dengan orang tua untuk mewujudkan kemandirian belajar peserta didik di era disrupsi pandemic covid19. Pemanfaatan fasilitas-fasilitas untuk menunjang pelaksanaan pembelajaran online tidak luput dari berbagai problema, karena tidak semua daerah terjangkau layanan internet. Kendala lainnya berupa biaya tambahan yang harus dialokasikan orang tua untuk kuota internet.

Bantuan kuota internet gratis dari pemerintah melalui Kementerian Pendidikan dan Kebudayaan (Kemendikbud) bisa diperolah dengan memasukkan data nomor ponsel ke Dapodik. Kuota gratis ini diberikan kepada siswa, guru, mahasiswa dan dosen. Bantuan ini akan diberikan mulai September hingga Desember 2020. Pendaftaran atau mengisian data nomor ponsel di Dapodik dibuka hingga 11 September 2020. ${ }^{15}$ Program kuota gratis dari Kementrian Pendidikan dan Kebudayaan juga tidak luput dari kendala bahkan ada peserta didik yang tidak dapat mengaksesnya. Berbagai kendala dalam pelaksanaan pembelajaran online dalam pendidikan jarak jauh merupakan bahan evaluasi untuk perbaikan baik secara nasional maupun regional. Karena era disrupsi pandemic covid-19 merupakan pelopor pembelajaran online yang kemungkinan akan tetap diterapkan dalam proses pembelajaran dalam pendidikan di Indonesia.

\section{Kinerja guru PAK}

a. Pengertian Kinerja

Istilah kinerja berasal dari bahasa Inggris terjemahan dari kata "performance". Kinerja bukan merupakan karakteristik seseorang seperti bakat atau kemampuan, tetapi perwujudan dari bakat atau kemampuan itu sendiri. ${ }^{16}$

\footnotetext{
${ }^{14}$ Luh Devi Herliandry*1, Nurhasanah2, Maria Enjelina Suban 3, Heru Kuswanto4, Pembelajaran Pada Masa Pandemi Covid-19., hlm 68.

${ }_{15}$ Yantina Debora, "Kuota Gratis Kemendikbud: Syarat, Cara Daftar dan Rincian Bantuan", https://tirto.id/kuota-gratis-kemendikbud-syarat-cara-daftar-dan-rincian-bantuan-f2ZU. Diakses, 2 Oktober 2020.

${ }^{16}$ Dr. Abd. Madjid, M. Ag, e-book Pengembangan Kinerja Guru Melalui: Kompetensi, Komitmen dan Motivasi Kerja (Yogyakarta: Samudra Biru, 2016), 10.
} 


\section{JURNAL LUXNOS}

Volume 6 Nomor 2, Desember 2020

Kinerja merupakan wujud dari unjuk kerja yang dihasilkan melalui bentuk kerja nyata. Kinerja dimaknai sebagai hasil kerja dalam bentuk kuantitas maupun kualitas dalam kurun waktu tertentu. Kinerja sebagai unjuk kerja prestasi kerja atau pelaksanaan kerja yang terukur dan bermanfaat bagi orang lain. Kinerja merupakan hasil-hasil kerja yang diperoleh dari fungsi-fungsi pekerjaan tertentu atau kegiatan tertentu selama masa kerja tertentu.

Kinerja merupakan kemampuan mempengaruhi orang lain untuk memberikan kontribusi kepada organisasi seperti (1) kuantitas keluaran, (2) kualitas keluaran, (3) jangka waktu keluaran, (4) kehadiran di tempat kerja, (5) sikap kooperatif. ${ }^{17}$ Kinerja merupakan hasil kerja yang dicapainya di sekolah tempatnya mengabdi, sesuai tanggung jawab yang diberikan sekolah untuk mewujudkan visi, misi, dan tujuan sekolah sesuai dengan standar moral maupun etos kerja dalam mewujudkan tujuan perubahan peserta didik dalam kognitif, psikomotorik dan afektif.

\section{b. Pengertian Guru Pendidikan Agama Kristen}

Guru adalah orang yang pekerjaannya (mata pencahariannya, profesinya) mengajar. ${ }^{18}$ Guru sebagai pribadi yang patut diteladani oleh para peserta didik dan masyarakat luas. Karena itu ada sebuah pribahasa berkata bahwa guru kencing berdiri, murid kencing berlari. Maksudnya bahwa, prilaku guru sangat mempengaruhi kelakuan para peserta didik, sebab guru selalu dicontoh mereka. Guru agama adalah guru yang mengajarkan mata pelajaran agama. ${ }^{19}$ Kristen artinya agama yang disampaikan oleh Kristus (Nabi Isa). ${ }^{20}$ Secara etimologis guru Pendidikan Agama Kristen adalah orang yang mengajarkan mata pelajaran agama Kristen yang diajarkan oleh Yesus Kristus. Guru Pendidikan Agama Kristen adalah orang yang belajar dan meneladani Yesus Kristus, untuk mengajarkannya dan memberikan teladan hidup Yesus Kristus dari dalam hidupnya kepada para peserta didiknya.

\footnotetext{
${ }^{17}$ Mathis dan Jackson, RL., Manajemen Sumber Daya Manusia. Penterjemah Jimmy Sadeli dan Bayu Prawira Hie. (Jakarta: Penerbit PT. Salemba Empat, 2010), 378.

18 Kamus Besar Bahasa Indonesia, off line. Diakses, 15 Oktober 2020

${ }^{19}$ Ibid

${ }^{20}$ Ibid
} 


\section{JURNAL LUXNOS}

Volume 6 Nomor 2, Desember 2020

Menurut Peraturan Menteri Negara Pendayagunaan Aparatur Negara dan Reformasi Birokrasi Nomor 16 Tahun 2009, penilaian kinerja guru adalah penilaian yang dilakukan terhadap setiap butir kegiatan tugas utama guru dalam rangka pembinaan karir, kepangkatan, dan jabatannya. Pelaksanaan tugas utama guru tidak dapat dipisahkan dari kemampuan seorang guru dalam penguasaan dan penerapan kompetensinya. Dalam hal ini adalah kompetensi yang sangat diperlukan bagi guru seperti yang diamanatkan oleh Peraturan Menteri Pendidikan Nasional Nomor 16 Tahun 2007 tentang Standar Kualifikasi Akademik dan Kompetensi Guru. Penguasaan dan penerapan kompetensi sangat menentukan tercapainya kualitas proses pembelajaran, pembimbingan peserta didik, dan pelaksanaan tugas tambahan yang relevan yang sesuai dengan fungsi sekolah/madrasah. Untuk itu, perlu dikembangkan sistem penilaian kinerja guru. ${ }^{21}$ Kinerja guru dinilai berdasarkan setiap butir tugas utama guru yang manunggal dengan kompetensi guru sesuai dengan amanat Peraturan Menteri Pendidikan Nasional Nomor 16 Tahun 2007 tentang Standar Kualifikasi Akademik dan Kompetensi Guru. Peningkatan kompetensi guru sangat erat korelasinya dengan kualitas kinerja guru dalam pelaksanaan pembelajaran, pembimbingan peserta didik dan pelaksanaan tugas tambahan sesuai fungsi sekolah.

Penilaian kinerja guru merupakan sistem yang didesain untuk mengevaluasi tingkatan kinerja guru secara individu dalam meningkatkan dan mencapai kinerja sekolah yang akan berdampak pada peningkatan prestasi peserta didik. Oleh karena itu, maka bentuk penilaian kinerja guru untuk melaksanakan pekerjaannya untuk meningkatkan kualitas pendidikan di sekolah tempatnya bertugas.

Pada dasarnya sistem penilaian kinerja guru bertujuan: 1). Menentukan tingkat kompetensi seorang guru; 2). Meningkatkan efisiensi dan efektivitas kinerja guru dan sekolah; 3). Menyajikan suatu landasan untuk pengambilan keputusan dalam mekanisme penetapan efektif atau kurang efektifnya kinerja guru; 4). Menyediakan landasan untuk program pengembangan keprofesian

\footnotetext{
${ }^{21}$ Pedoman Pelaksanaan Penilaian Kinerja Guru, https://akhmadsudrajat.files.wordpress.com/2012/07/buku-2-pedoman-pkg.pdf. hlm. 5. Diakses, 15 Oktober 2020.
} 


\section{JURNAL LUXNOS \\ Volume 6 Nomor 2, Desember 2020}

berkelanjutan bagi guru; 5). Menjamin bahwa guru melaksanakan tugas dan tanggung-jawabnya serta mempertahankan sikap-sikap yang positif dalam mendukung pembelajaran peserta didik untuk mencapai prestasinya; 6). Menyediakan dasar dalam sistem peningkatan promosi dan karir guru serta bentuk penghargaan lainnya. 22 Tujuan penilaian kinerja guru untuk meningkatkan kompetensi guru, sehingga dapat bekerja secara efisien dan efektif yang berkualitas sebagai jaminan yang mendukung prestasi kerjanya, untuk promosi kariernya sebagai pengajar profesional. Jika penilaian kinerja guru ini disadari dan diikuti dengan benar oleh para guru termasuk guru PAK, maka kualitas pendidikan di Indonesia akan semakin meningkat dan dapat bersaing di dunia internasional.

c. Dasar hukum Kinerja Guru

Dasar Hukum kinerja guru di Indonesia diatur oleh pemerintah dalam berbagai kebijakan baik dalam undang-undang maupun peraturan pemerintah, sebagai berikut:

1) Undang Undang Nomor 20 Tahun 2003 tentang Sistem Pendidikan Nasional.

2) Undang Undang Nomor 14 Tahun 2005 tentang Guru dan Dosen.

3) Peraturan Menteri Pendidikan Nasional Nomor 16 Tahun 2007 tentang Standar Kualifikasi Akademik dan Kompetensi Guru.

4) Peraturan Pemerintah Nomor 74 Tahun 2008 tentang Guru.

5) Peraturan Menteri Pendidikan Nasional Nomor 27 Tahun 2008 tentang Standar Kualifikasi Akademik dan Kompetensi Konselor.

6) Peraturan Menteri Negara Pendayagunaan Aparatur Negara dan Reformasi Birokrasi Nomor 16 Tahun 2009 tentang Jabatan Fungsional Guru dan Angka Kreditnya.

7) Peraturan Menteri Pendidikan Nasional Nomor 28 Tahun 2010 tentang Penugasan Guru sebagai Kepala Sekolah/Madrasah.

8) Peraturan Bersama Menteri Pendidikan Nasional dan Kepala Badan Kepegawaian Negara Nomor 03/V/PB/2010 dan Nomor 14 Tahun 2010 tentang Petunjuk Pelaksanaan Jabatan Fungsional Guru dan Angka Kreditnya.

\footnotetext{
${ }^{22}$ Pedoman Pelaksanaan Penilaian Kinerja Guru, hlm. 5. Diakses, 15 Oktober 2020.
} 


\section{JURNAL LUXNOS}

Volume 6 Nomor 2, Desember 2020

9) Peraturan Negara Pendidikan Nasional Nomor: 35 Tahun 2010 tentang Petunjuk Teknis Jabatan Fungsional Guru dan Angka Kreditnya. ${ }^{23}$

Penerbitan dasar hukum kinerja guru oleh pemerintah merupakan jaminan bagi guru untuk dapat meningkatkan kompetensi diri secara individu bagi kualitas kinerjanya melalui tugas tanggung jawabnya di sekolah tempatnya mengajar. Pada dasarnya kualitas kinerja guru merupakan dampak dari peningkatan kompetensinya yang dapat mempromosikan dirinya sebagai pengajar profesional. Berdasarkan penerbitan dasar hukum kinerja guru, maka guru-guru dapat berinisiatif untuk meningkatkan kompetensi diri baik secara pribadi maupun melalui berbagai sarana yang dipersiapkan pemerintah. Tujuan penerbitan dasar hukum kinerja guru, sebagai landasan yang mengatur berbagai langkah-langkah teknis untuk menjadi panduan bagi para guru meningkatkan kompetensi dirinya bagi kualitas kinerjanya sehingga meningkatkan kualitas pendidikan di Indonesia, sebagai panggilan tertinggi didalam profesinya sebagai guru.

Kurangnya literasi buku-buku PAK untuk pendidikan dasar, menengah dan Sekolah Tinggi Teologi di Indonesia, sebagai indikasi bahwa kinerja guru PAK masih rendah. Sebab salah satu wujud nyata dari prestasi kinerja guru dan dosen adalah publikasi karya tulis ilmiah berupa buku ajar. Hal ini disebabkan oleh kurangnya kesadaran guru PAK dalam meningkatkan kompetensi diri yang menunjang kualitas kinerjanya. Selain kurangnya kesadaran, juga kurangnya pengawasan kinerja guru oleh departemen-departemen terkait, berhubungan dengan urusan kelengkapan kenaikan pangkatan atau jabatan fungsional yang hanya sebagai pelengkap persyaratan dan bukan sebagai ajang unjuk kinerja dalam menunjang profesi.

Perkembangan ilmu pengetahuan dan teknologi menjadi hambatan bagi guru PAK yang tidak menyadari pentingnya peningkatan kompetensi diri bagi kualitas kinerjanya. Hal ini terlihat di era revolusi industri 4.0 yang menjadi disrupsi bagi guru-guru PAK yang belum siap beralih dari proses pembelajaran konvensional ke proses pembelajaran berbasis teknologi. Sebab era revolusi industri 4.0 menuntut pengembangan kompetensi guru PAK untuk peningkatan kinerja dalam mengindentifikasi permasalahan dalam penerapan pembelajaran

${ }^{23}$ Ibid 


\section{JURNAL LUXNOS}

Volume 6 Nomor 2, Desember 2020

online, menemukan solusi dalam permasalahan yang terjadi, merencanakan dan melaksanakan pembelajaran online, serta mengadakan evaluasi terhadap proses dan hasil pembelajaran online berbasis internet. Era revolusi Industri 4.0 sebagai disrupsi yang menuntut guru PAK agar mampu memahami dan menggunakan teknologi canggih dalam meningkatkan kualitas proses pembelajaran berbasis online. Oleh karena itu, guru PAK harus menyadari dan berupaya untuk meningkatkan dan mengembangkan kompetensi dirinya bagi peningkatan kualitas kinerjanya, terkait dengan pelaksanaan pendidikan di Indonesia.

Tuntutan pemanfaatan teknologi canggih dalam pembelajaran berbasis online di era revolusi 4.0 dan masa pandemic covid-19 sebagai disrupsi guru PAK dalam pelaksanaan pembelajaran online, karena terjadinya perubahan terhadap sistem pelaksanaan pendidikan di Indonesia yang beralih dari pembelajaran konvensional ke pembelajaran online, yang memaksa guru PAK untuk meningkatkan kompetensinya bagi kualitas kinerjanya dalam peran dan fungsinya sebagai pengajar dan pendidik. Harus ada upaya peningkatan kompetensi guru melalui kegiatan-kegiatan seminar, diklat, dan pelatihan dan bahkan studi lanjut. ${ }^{24}$ Pemerintah melalui Kementerian Pendidikan dan Kebudayaan harus memfasilitasi para guru termasuk guru PAK harus meningkatkan komptensi bagi kualitas kinerjanya dengan menyediakan infrastruktur utama termasuk internet agar menjangkau daerah-daerah terluar sehingga dapat mengakses berbagai perkembangan informasi berhubungan dengan pembelajaran online, sehingga berinovasi untuk meningkatkan kinerjanya dalam pelaksnaan pendidikan berbasis online.

\section{Kesimpulan}

Era disrupsi bagi kinerja guru PAK merupakan dampak dari era revolusi industri 4.0 dan pandemic covid - 19. Era revolusi industri 4.0 dan era pandemic covid - 19 merupakan era disrupsi karena menimbulkan gangguan bagi kenyamanan, ketentraman dan kesejahteraan guru PAK dalam menjalankan tugas dan tanggung jawabnya dalam mengajar dan mendidik para peserta

${ }^{24}$ Dinar Wahyuni, Peningkatan Kompetensi Guru Menuju Era Revolusi Industri 4.0 Pusat Penelitian Badan Keahlian DPR RI. Vol. X, No. 24/II/Puslit/Desember/2018. Diakses, 3 Oktober 2020 


\section{JURNAL LUXNOS}

Volume 6 Nomor 2, Desember 2020

didiknya secara konvensional. Perkembangan ilmu pengetahuan dan teknologi (IPTEK) menemukan dan melahirkan era revolusi industri mulai 1.0 sampai sekarang kita berada di 4.0 yang menuntut semua sisi kehidupan manusia harus menggunakan teknologi komunikasi digital.

Perkembangan ini menuntut guru PAK meninggalkan model pembelajaran konvensional dan beralih ke model pembelajaran online dengan menggunakan teknologi digital. Sekaligus guru PAK harus meningkatkan kompetensinya melalui seminar, workshop, diklat, belajar mandiri dan bahkan harus studi lanjut agar dapat mengikuti tuntutan perkembangan zaman. Selain disrupsi sebagai dampak dari revolusi industri 4.0, pada Maret 2020 Covid - 19 mewabah dan menjadi pandemi covid - 19 di Indonesia, yang memaksa seluruh elemen masyarakat untuk bekerja dan beraktifitas dari rumah saja atau online. Kebijakan pemerintah untuk pembatasan sosial bersekala besar (PSBB) dan belajar dari rumah memaksa guru PAK untuk meningkatkan kinerjanya dalam memanfaatkan teknologi digital dalam pelaksanaan pembelajaran jarak jauh atau pembelajaran online melalui aplikasi seperti aplikasi Zoom, Google meet, Google Classroom, Microsoft team dan palikasi lainnya layaknya di ruang kelas hanya saja secara jarak jauh.

Pemerintah melalui KEMENDIKBUD memfasilitasi para guru termasuk guru PAK agar meningkatkan komptensi kinerjanya agar dapat menggunakan infrastruktur pembelajaran online yang telah dipersiapkan pemerintah. Guruguru termasuk guru PAK harus mampu bersaing dalam penerapan pembelajaran

online, dengan meningkatkan kinerjanya dalam pelaksanaan pendidikan berbasis online sebagai dampak dari disrupsi revolusi industri 4.0 dan pandemic covid -19.

\section{Referensi}

Abd. Madjid, M. Ag, e-book Pengembangan Kinerja Guru Melalui:

Kompetensi, Komitmen dan Motivasi Kerja. Yogyakarta: Samudra Biru, 2016.

Rhenald Kasali, Disruption: Tak ada yang tak bisa diubah sebelum dihadapi, Motivasi saja tidak cukup. Jakarta: Gramedia Pustaka Utama, 2017.

Kusuma, J. W., \& Hamidah. (2020). Platform Whatsapp Group Dan Webinar Zoom Dalam Pembelajaran Jarak Jauh Pada Masa Pandemik Covid 19. Jurnal Ilmiah Pendidikan Matematika Volume, 5(1). 


\section{JURNAL LUXNOS}

Volume 6 Nomor 2, Desember 2020

Abidah, A., Hidaayatullaah, H. N., Simamora, R. M., Fehabutar, D., \& Mutakinati, L. (2020). The Impact of Covid-19 to Indonesian Education and Its Relation to the Philosophy of "Merdeka Belajar." Studies in Philosophy of Science and Education, 1(1), 38-49.

https://sciejournal.com/index.php/SiPoSE/article/view/9.

Dinar Wahyuni, Peningkatan Kompetensi Guru Menuju Era Revolusi Industri 4.0 Pusat Penelitian Badan Keahlian DPR RI. Vol. X, No. 24/II/Puslit/Desember/2018.

Kamus Besar Bahasa Indonesia. https://romeltea.com/pengertiandisrupsi-dan-contohnya/.

Luh Devi Herliandry*1, Nurhasanah'2, Maria Enjelina Suban ${ }^{3}$, Heru Kuswanto ${ }^{4}$, Pembelajaran Pada Masa Pandemi Covid-19. Jurnal Teknologi Pendidikan http://journal.unj.ac.id/unj/index.php/jtp Vol. 22, No. 1, April 2020, e-ISSN: 2620-3081; p-ISSN: 1411-2744; DOI: https://doi.org/10. 21009/jtp.v22i1.15286.

Mathis dan Jackson, RL., Manajemen Sumber Daya Manusia. Penterjemah Jimmy Sadeli dan Bayu Prawira Hie. Jakarta: Penerbit PT. Salemba Empat, 2010

Merdeka.com,s Data Terkini Jumlah Korban Virus Corona di Indonesia. https://www.merdeka.com/peristiwa/data-terkini-jumlah-korban-virus-coronadi-indonesia.html

Pedoman Pelaksanaan Penilaian Kinerja Guru, https://akhmadsudrajat.files.wordpress.com/2012/07/buku-2-pedomanpkg.pdf.

Sudaryono, "Bunuh Diri Masal Perguruan Tinggi Menuju Pendidikan Asembling," Sumber: http://amikhb.ac.id/detailpost/bunuh-diri-masalperguruan-tinggi-menuju-pendidikan-asembling.

Sukartono, Revolusi Industri 4.0 dan Dampaknya terhadap Pendidikan di Indonesia, FIP PGSD Universitas Muhammadiyah Surakarta. fkip.ums.ac.id/.../

Verawardina, U., Asnur, L., Lubis, A. L., \& Hendriyani, Y. (2020). Reviewing Online Learning Facing the Covid-19 Outbreak. 12(3), 385-392.

Wikipedia; Industri 4.0 adalah nama tren otomasi dan pertukaran data terkini dalam teknologi pabrik. Istilah ini mencakup sistem siber-fisik, internet untuk segala, komputasi awan, dan komputasi kognitif. https://id.wikipedia.org/wiki/Industri_4.0. 


\section{JURNAL LUXNOS}

Volume 6 Nomor 2, Desember 2020

Wiranda, T., \& Adri, M. (2019). Rancang Bangun Aplikasi Modul

Pembelajaran Teknologi WAN Berbasis Android. VoteTEKNIKA (Vocational Teknik Elektronika dan Informatika), 7(4), 2302- 3295.

Yantina Debora, "Kuota Gratis Kemendikbud: Syarat, Cara Daftar dan

Rincian Bantuan", https://tirto.id/kuota-gratis-kemendikbud-syarat-cara-daftardan-rincian-bantuan-f2ZU. 